\title{
Pharmacokinetics of Ebeiedinone in Mouse Blood by UPLC-MS/MS
}

\author{
Yongxi Jin ${ }^{1} \dagger$, Yuyan Chen ${ }^{2} \dagger$, Jiawen $\mathrm{Liu}^{2}, \mathrm{Xi} \mathrm{Bao}^{3}$, Yinghao $\mathrm{Zhi}^{1}$, Congcong $\mathrm{Wen}^{2 *}$ and Wenzong $\mathrm{Zhu}^{{ }^{*}}$ \\ ${ }^{\prime}$ Department of Rehabilitation, Wenzhou Municipal Hospital of Traditional Chinese Medicine, Wenzhou 325005, China \\ ${ }^{2}$ Laboratory Animal Center, Wenzhou Medical University, Wenzhou 325035, China \\ ${ }^{3}$ The First Affiliated Hospital of Wenzhou Medical University, WenZhou 325000, China
}

Received: 11 Jul 2019; accepted: 30 Aug 2019

\begin{abstract}
An ultra-performance liquid chromatography-tandem mass spectrometry (UPLC-MS/MS) method was established to determine ebeiedinone in mouse blood, and the pharmacokinetics of ebeiedinone after intravenous $(0.5 \mathrm{mg} / \mathrm{kg})$ and oral $(2,4$, and $8 \mathrm{mg} / \mathrm{kg}$ ) administration was studied. Twenty-four mice were randomly divided into 4 groups, 1 group was for intravenous administration $(0.5 \mathrm{mg} / \mathrm{kg})$, and other 3 groups were for oral administration $(2,4$, and $8 \mathrm{mg} / \mathrm{kg}$ ), with 6 rats in each group. Yubeinine was used as an internal standard. Multiple reaction monitoring (MRM) mode was used to quantitatively analyzed ebeiedinone $\mathrm{m} / \mathrm{z} 414.4 \rightarrow 91.1$ and the internal standard $\mathrm{m} / \mathrm{z}$ $430.4 \rightarrow 412.3$ in the electrospray ionization (ESI) positive interface. In the concentration range of $1-2000 \mathrm{ng} / \mathrm{mL}$, the ebeiedinone in the mouse blood was linear $\left(r^{2}>0.995\right)$, and the lower limit of quantification was $1.0 \mathrm{ng} / \mathrm{mL}$. In the mouse blood, the intra-day precision coefficient of variation $(\mathrm{CV})$ was less than $15 \%$, and the inter-day precision CV was less than $15 \%$. The accuracy ranged from $85.4 \%$ to $114.6 \%$, and the average recovery was higher than $61.3 \%$. The matrix effect was between $87.0 \%$ and $106.5 \%$. These data met the pharmacokinetic study requirements of ebeiedinone. The UPLC-MS/MS method was sensitive, rapid, and selective and was successfully applied to the pharmacokinetic study of ebeiedinone in mice. The absolute bioavailability of ebeiedinone was $30.6 \%$.
\end{abstract}

Keywords: Ebeiedinone, pharmacokinetics, bioavailability, mouse, UPLC-MS/MS

\section{Introduction}

Fritillaria thunbergii Miq. is the authentic medicinal material of Zhejiang Province [1]. It is also known as Zhebei, Dabei, Xiangbei, Yuanbao, and Zhubei [2-4]. It is a traditional Chinese herbal medicine. It is listed as one of the "Zheba Flavors" and in the Chinese Pharmacopoeia; it has the functions of clearing away heat, relieving cough, reducing toxins, and removing phlegm, and is commonly prescribed in traditional Chinese medicine [5-7]. Zhejiang Fritillaria has a long history of application in traditional Chinese medicine, and it has a wide application and satisfactory results [8-10]. Fritillaria has active ingredients such as alkaloids, polysaccharides, and total saponins [11], among which alkaloids include verticine, peimine, verticinone, peiminine, zhebeinine, zhebeirine, eduardine, zhebeinone, peimisine, isoverticine, and ebeiedinone [1]. Therefore, it was necessary to establish an analytical method to monitor the concentration of ebeiedinone.

There were several gas chromatography methods developed for determination of ebeiedinone in bulbs of Fritillaria $[12,13]$; however, there were no ultra-performance liquid chromatography-tandem mass spectrometry (UPLC-MS/MS) reported for the determination of ebeiedinone. To the best of our knowledge, the pharmacokinetics of ebeiedinone had not been reported. In this paper, UPLC-MS/MS method was established to determine ebeiedinone in mouse blood, the pharmacokinetics of ebeiedinone after intravenous (IV) and oral (PO) administration was studied, and the absolute bioavailability was obtained.

*Author for correspondence: E-mail: bluce494949@163.com (C.W.), E-mail: zhuwenzongwwz@163.com (W.Z.).

$\dagger$ These authors contributed to work equal.

\section{Experimental}

2.1. Chemicals and Animals. Ebeiedinone (purity $>98 \%$, Figure 1A) and yubeinine (internal standard [IS], purity $>98 \%$, Figure 1B) were purchased from Chengdu Mansite Pharmaceutical Co., Ltd. Chromatographically pure acetonitrile and methanol were purchased from Merck Co., Ltd. (Darmstadt, Germany). Ultrapure water was prepared by a Millipore Milli-Q purification system (Bedford, MA, USA). Institute of Cancer Research (ICR) mice (body weight: 20$22 \mathrm{~g}$ ) were purchased from the Animal Experimental Center of Wenzhou Medical University.

2.2. Instrument and Conditions. ACQUITY I-Class UPLC with XEVO TQS-micro triple quadrupole mass spectrometer (Waters Corp, Milford, MA, USA) was used for determination of ebeiedinone in mouse blood. Masslynx 4.1 software (Waters Corp.) was used for data acquisition and instrument control.

The column was UPLC ethylene bridged hybrid (BEH) C18 $(2.1 \mathrm{~mm} \times 50 \mathrm{~mm}, 1.7 \mu \mathrm{m})$, and the column temperature was set to $30{ }^{\circ} \mathrm{C}$. The mobile phase consisted of acetonitrile and $0.1 \%$ formic acid with a gradient elution at a flow rate of $0.4 \mathrm{~mL} / \mathrm{min}$ and an elution time of $4 \mathrm{~min}$. The gradient elution was as follows: $0-0.2 \mathrm{~min}$, acetonitrile $10 \% ; 0.2-1.5 \mathrm{~min}$, acetonitrile $10 \%-85 \% ; 1.5-2.0 \mathrm{~min}$, acetonitrile $85 \% ; 2.0$ $2.5 \mathrm{~min}$, acetonitrile $85 \%-10 \%$; and $2.5-4.0 \mathrm{~min}$, acetonitrile $10 \%$.

Nitrogen was used as the desolvation gas $(800 \mathrm{~L} / \mathrm{h})$ and the cone gas $(50 \mathrm{~L} / \mathrm{h})$. The capillary voltage was set to $2.0 \mathrm{kV}$, the ion source temperature was $150{ }^{\circ} \mathrm{C}$, and the desolvation temperature was $400{ }^{\circ} \mathrm{C}$. Multiple reaction monitoring (MRM) mode was used to quantitatively analyzed ebeiedinone $\mathrm{m} / \mathrm{z}$ $414.4 \rightarrow 91.1$ and the internal standard $\mathrm{m} / \mathrm{z} 430.4 \rightarrow 412.3$ in

This is an open-access article distributed under the terms of the Creative Commons Attribution-NonCommercial 4.0 International License (https://creativecommons.org/licenses/by-nc/4.0/), which permits unrestricted use, distribution, and reproduction in any medium for non-commercial purposes, provided the original author and source are credited, a link to the CC License is provided, and changes - if any - are indicated. 


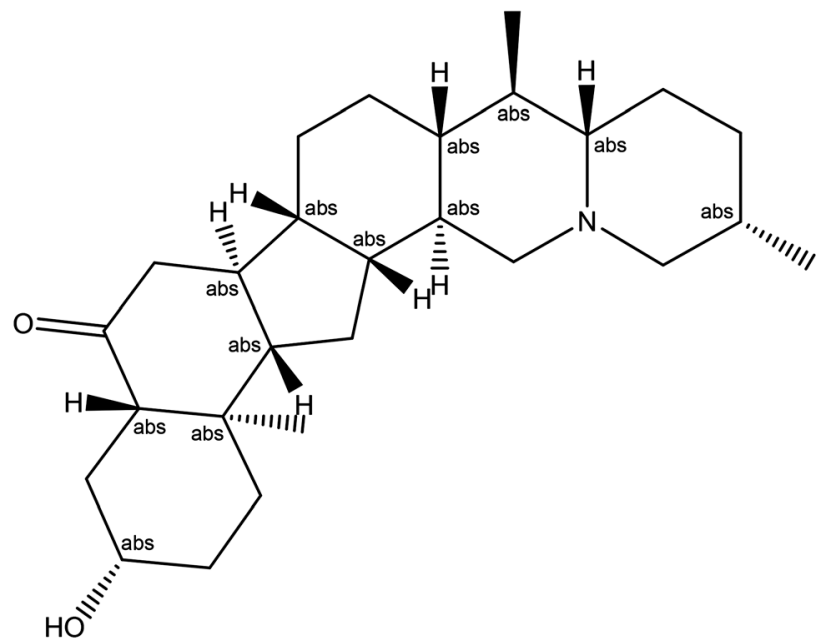

(A)

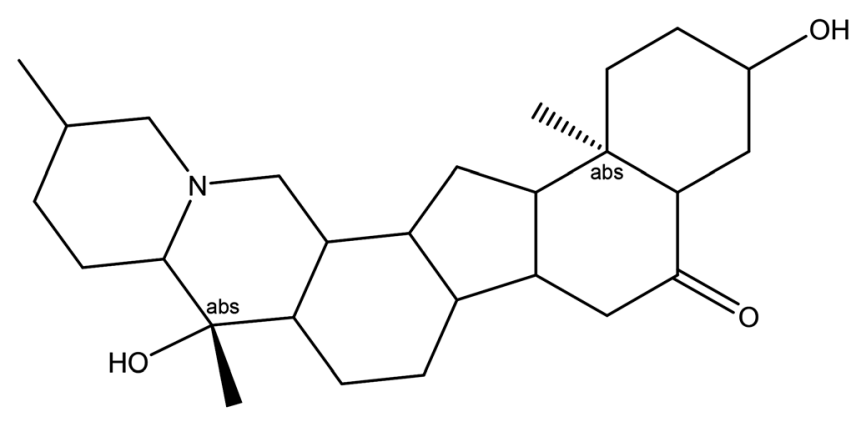

(B)

Figure 1. Chemical structure of ebeiedinone (A) and yubeinine (internal standard, B)

the electron spray ionization (ESI) positive interface (Figure 2).

2.3. Reference Solution Preparation. A stock solution of ebeiedinone $(1.0 \mathrm{mg} / \mathrm{mL})$ and yubeinine $(1.0 \mathrm{mg} / \mathrm{mL})$ were prepared with methanol-water (50:50), respectively. A series of working solutions with different concentrations (10, 30, $50,200,500,1800,2000,4500,5000,10,000,18,000$, and $20,000 \mathrm{ng} / \mathrm{mL}$ ) of ebeiedinone were prepared by diluting an ebeiedinone stock solution with methanol. A solution of the internal standard yubeinine $(50 \mathrm{ng} / \mathrm{mL})$ was prepared by diluting a stock solution of yubeinine with acetonitrile. All solutions were stored at $4{ }^{\circ} \mathrm{C}$.

2.4. Standard Curve Preparation. The blank mouse blood was mixed with an appropriate amount of standard working solution to prepare the blood standard curve of ebeiedinone, and the concentration of ebeiedinone in the blood of mice was 1, 5, 20, 50, 200, 500, 1000, and $2000 \mathrm{ng} / \mathrm{mL}$. The standard curve ranges from 1 to $2000 \mathrm{ng} / \mathrm{mL}$. Quality Control (QC) samples were prepared in the same manner as the standard curve, with 4 blood concentrations $(1,3,450$, and $1800 \mathrm{ng} /$ $\mathrm{mL})$.

2.5. Sample Processing. A $20-\mu \mathrm{L}$ blood sample was added into an $1.5-\mathrm{mL}$ Eppendorf tube, and then $100 \mu \mathrm{L}$ of acetonitrile (containing $50 \mathrm{ng} / \mathrm{mL}$ yubeinine) was added, vortexed for $1.0 \mathrm{~min}$, and centrifuged at $4{ }^{\circ} \mathrm{C}$ for $1 \mathrm{~min}$ at $13,000 \mathrm{rpm}$. The supernatant $(80 \mu \mathrm{L})$ was taken into the inner tube of the sample bottle, and $2 \mu \mathrm{L}$ injected into UPLC-MS/ MS for analysis.

2.6. Method Validation. The verification method was established in accordance with the US Food and Drug Administration (FDA) bioanalytical method validation guidelines [14-19]. Validation projects included selectivity, matrix effects, linearity, precision, accuracy, recovery, and stability [20-24].

The selectivity of the method was evaluated by analyzing 6 lots of different sources of blank mouse blood, blank blood spiked with ebeiedinone, and the IS.

Calibration curves were obtained by analyzing spiked calibration samples on 3 separate days. Peak area ratios of ebeiedinone to IS where plotted against ebeiedinone concentrations. Standard curves were well fitted to the equations by linear regression, with a weighting factor of the reciprocal of the concentration $(1 / x)$ in the concentration range of $1-2000 \mathrm{ng} / \mathrm{mL}$ for mouse blood. The lower limit of quantitation (LLOQ) was defined as the lowest concentration on the calibration curves.

To evaluate the matrix effect, blank mouse blood was extracted and then spiked with the analyte at 1, 3, 450, and $1800 \mathrm{ng} / \mathrm{mL}(n=6)$. The corresponding peak areas were then compared to those of neat standard solutions at equivalent concentrations, and this peak area ratio is defined as the matrix effect.

Accuracy and precision were evaluated by the determination of QC samples at 4 concentration levels $(1,3,450$, and $1800 \mathrm{ng} / \mathrm{mL}$ ) in 6 replicates over 3 validation. The precision is expressed in terms of coefficient of variation (CV).

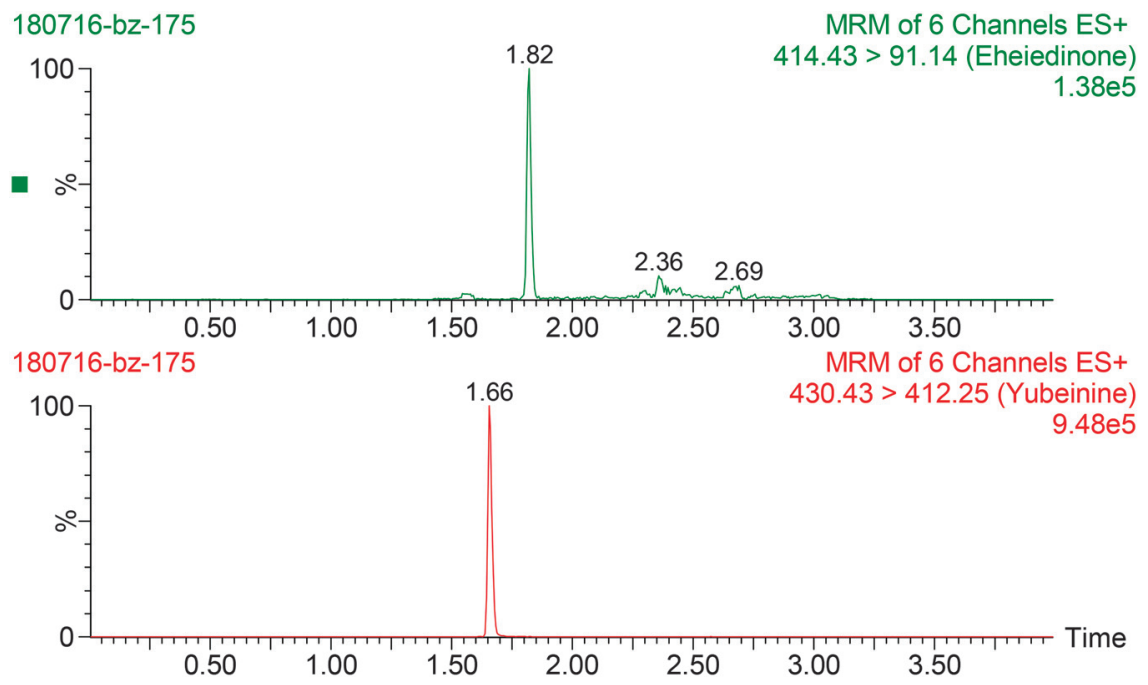

Figure 2. UPLC-MS/MS of ebeiedinone and yubeinine (internal standard) in mouse blood 
Table 1. Accuracy, precision, matrix effect, and recovery of ebeiedinone in the mouse blood

\begin{tabular}{|c|c|c|c|c|c|c|}
\hline \multirow{2}{*}{$\begin{array}{l}\text { Concentration } \\
(\mathrm{ng} / \mathrm{mL})\end{array}$} & \multicolumn{2}{|c|}{ Accuracy (\%) } & \multicolumn{2}{|c|}{ Precision $(\mathrm{CV} \%)$} & \multirow{2}{*}{$\begin{array}{l}\text { Matrix effect } \\
(\%)\end{array}$} & \multirow{2}{*}{$\begin{array}{c}\text { Recovery } \\
(\%)\end{array}$} \\
\hline & Intra-day & $\overline{\text { Inter-day }}$ & Intra-day & $\overline{\text { Inter-day }}$ & & \\
\hline$\overline{1}$ & 114.6 & 85.4 & 14.1 & 11.1 & 87.0 & 65.6 \\
\hline 3 & 99.4 & 109.7 & 12.9 & 14.5 & 88.5 & 61.3 \\
\hline 180 & 107.1 & 108.2 & 10.8 & 9.2 & 93.6 & 70.8 \\
\hline 1800 & 96.6 & 100.8 & 6.4 & 10.8 & 106.5 & 64.1 \\
\hline
\end{tabular}

The recovery of ebeiedinone was evaluated by comparing the peak area of extracted QC samples with those of the reference QC solutions reconstituted in blank mouse blood extracts $(n=6)$.

The stability of ebeiedinone in mouse blood was evaluated by analyzing 3 replicates of the blood samples $(3,450$, and $1800 \mathrm{ng} / \mathrm{mL}$ ) exposed to different conditions. These results were compared with that of the freshly-prepared blood samples. Short-term stability was determined after the exposure of the spiked samples to room temperature for $2 \mathrm{~h}$, and the ready-to-inject samples (after protein precipitation) in the UPLC autosampler at room temperature for $24 \mathrm{~h}$. Freeze-thaw stability was evaluated after 3 complete freeze-thaw cycles $\left(-20\right.$ to $25^{\circ} \mathrm{C}$ ) on consecutive days. Long-term stability was assessed after storage of the standard spiked blood samples at $-20{ }^{\circ} \mathrm{C}$ for 20 days $[25,26]$.

2.7. Pharmacokinetic Study. About $8.0 \mathrm{mg}$ of ebeiedinone was dissolved in purified water containing $0.01 \% \mathrm{HCl}$ and prepared into a $1.0 \mathrm{mg} / \mathrm{mL}$ drug solution, freshly prepared before the experiment. All experimental procedures and protocols were reviewed and approved by the Animal Care and Use Committee of Wenzhou Medical University. Twenty-
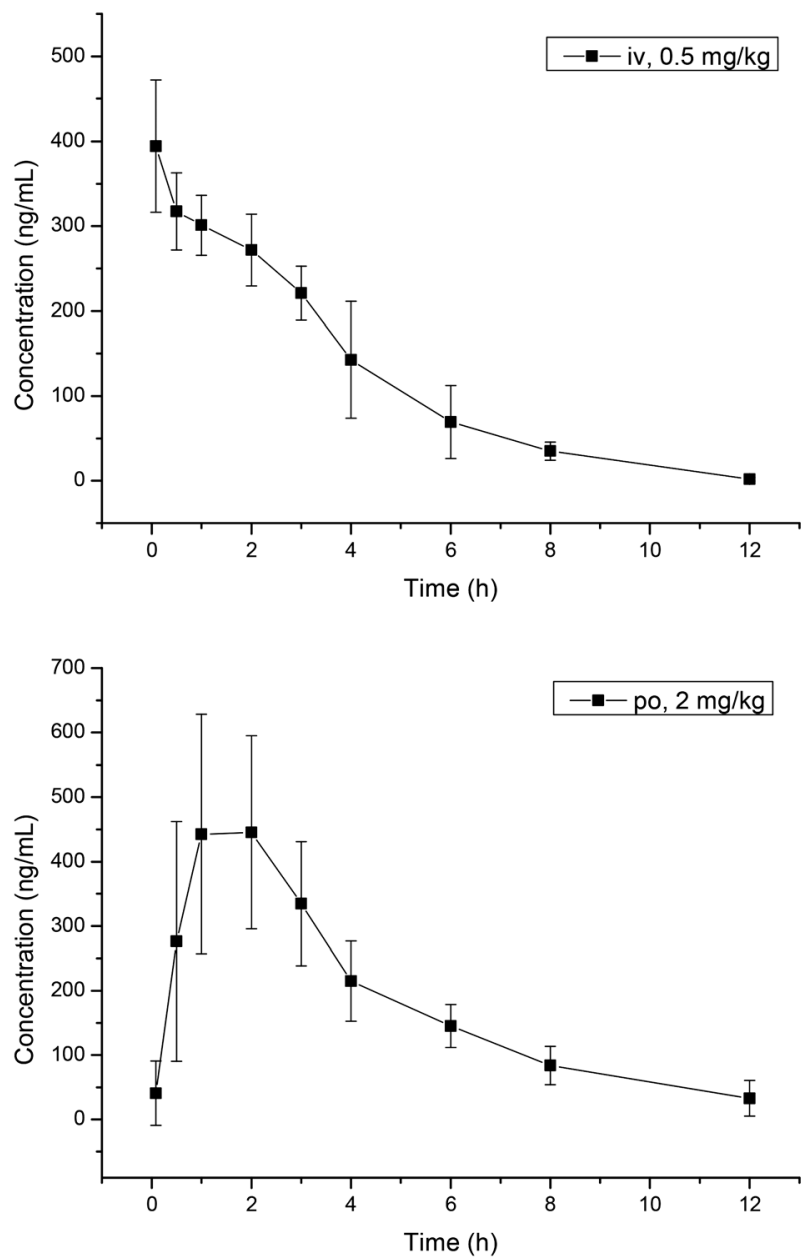

four mice were randomly divided into 4 groups, 1 group was for intravenous administration $(0.5 \mathrm{mg} / \mathrm{kg})$, and the other 3 groups were for oral administration $(2,4$, and $8 \mathrm{mg} / \mathrm{kg}$ ), with 6 rats in each group. Then, $20 \mu \mathrm{L}$ of blood was obtained in a 1.5-mL Eppendorf tube from tail vein at $5 \mathrm{~min}, 0.5,1,1.5,2$, 3,4 , and $8 \mathrm{~h}$ after intravenous or oral administration in mice, and was frozen at $-20{ }^{\circ} \mathrm{C}$.

DAS 2.0 software (China Pharmaceutical University) was used to analyze pharmacokinetic parameters. The formula for bioavailability was absolute bioavailability $=$ oral administration AUC/intravenous AUC $\times 100 \%$ [27-30].

\section{Results and Discussion}

3.1. Method Optimization. ESI positive and negative selection was often evaluated in methodological studies [3136]. Ebeiedinone was a basic compound, more suitable for ESI positive detection. Our experiments verified that the ESI positive ion mode was more sensitive than the negative one.

Liquid chromatography conditions separate the endogenous interfering substances as much as possible from the analyte and the internal standard at a retention time [37-40]. We tried
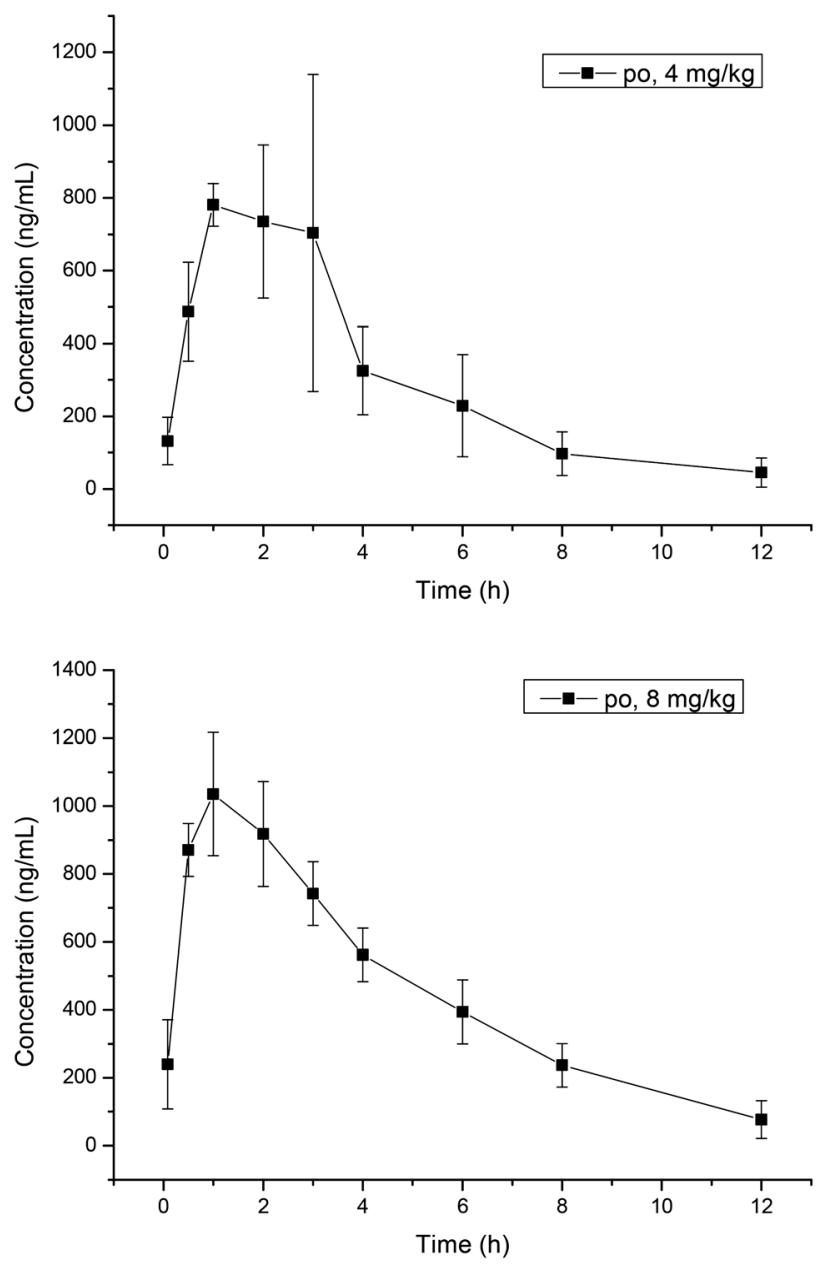

Figure 3. Time-blood concentration curve of ebeiedinone in mouse blood after intravenous $(0.5 \mathrm{mg} / \mathrm{kg})$ and oral $(2,4$, and $8 \mathrm{mg} / \mathrm{kg})$ administration 
Table 2. Main pharmacokinetic parameters of ebeiedinone in mice

\begin{tabular}{|c|c|c|c|c|c|}
\hline Parameters & Unit & IV $(0.5 \mathrm{mg} / \mathrm{kg})$ & PO $(2 \mathrm{mg} / \mathrm{kg})$ & $\mathrm{PO}(4 \mathrm{mg} / \mathrm{kg})$ & PO $(8 \mathrm{mg} / \mathrm{kg})$ \\
\hline$\overline{\mathrm{AUC}_{(0-t)}}$ & $\mathrm{ng} / \mathrm{mL} \mathrm{h}$ & $1440.0 \pm 187.4$ & $2178.4 \pm 557.2$ & $3606.6 \pm 997.0$ & $5259.7 \pm 530.9$ \\
\hline $\mathrm{AUC}_{(0-\infty)}$ & $\mathrm{ng} / \mathrm{mL} \mathrm{h}$ & $1448.6 \pm 189.9$ & $2378.0 \pm 641.2$ & $3946.0 \pm 1267.8$ & $5867.9 \pm 987.2$ \\
\hline $\operatorname{MRT}_{(0-t)}$ & $\mathrm{h}$ & $2.8 \pm 0.2$ & $3.8 \pm 0.5$ & $3.3 \pm 0.6$ & $3.7 \pm 0.4$ \\
\hline $\operatorname{MRT}_{(0-\infty)}$ & $\mathrm{h}$ & $2.9 \pm 0.2$ & $4.9 \pm 1.4$ & $4.6 \pm 2.0$ & $4.8 \pm 0.9$ \\
\hline$t_{1 / 2 z}$ & $\mathrm{~h}$ & $1.4 \pm 0.6$ & $3.1 \pm 1.5$ & $3.5 \pm 2.8$ & $3.0 \pm 0.9$ \\
\hline$t_{\max }$ & $\mathrm{h}$ & 0.1 & $1.6 \pm 0.5$ & $2.2 \pm 0.8$ & $1.3 \pm 0.5$ \\
\hline $\mathrm{CL}_{\mathrm{z} / \mathrm{F}}$ & $\mathrm{L} / \mathrm{h} / \mathrm{kg}$ & $0.4 \pm 0.1$ & $0.9 \pm 0.2$ & $1.1 \pm 0.4$ & $1.4 \pm 0.2$ \\
\hline$V_{\mathrm{z} / \mathrm{F}}$ & $\mathrm{L} / \mathrm{kg}$ & $0.7 \pm 0.3$ & $3.8 \pm 1.7$ & $4.9 \pm 2.6$ & $6.0 \pm 1.5$ \\
\hline$C_{\max }$ & $\mathrm{ng} / \mathrm{mL}$ & $394.3 \pm 77.8$ & $471.1 \pm 175.7$ & $989.9 \pm 173.0$ & $1062.1 \pm 161.7$ \\
\hline Bioavailabilit & & & $37.8 \%$ & $31.3 \%$ & $22.8 \%$ \\
\hline
\end{tabular}

The area under the plasma concentration-time curve (AUC), the mean residence time (MRT), the half-life $\left(t_{1 / 2}\right)$, the plasma clearance (CL), the apparent

distribution volume $(V)$, and the maximum plasma concentration $\left(C_{\max }\right)$.

methanol-water, methanol-0.1\% formic acid, methanol-10 $\mathrm{mmol} / \mathrm{L}$ ammonium acetate (containing $0.1 \%$ formic acid), acetonitrile-water, acetonitrile- $0.1 \%$ formic acid, and acetonitrile $-10 \mathrm{mmol} / \mathrm{L}$ ammonium acetate (containing $0.1 \%$ formic acid) and using gradient elution. It was found that acetonitrile- $0.1 \%$ formic acid gave the most satisfactory peak shape and retention time.

3.2. Method Validation. The retention times of ebeiedinone and internal standard were 1.82 and $1.66 \mathrm{~min}$ in Figure 2, respectively. No obvious impurities and endogenous substances interfered with the detection, indicating that the selectivity of the method was good.

The standard curve equation of ebeiedinone in the mouse blood was $Y=0.0019 C+0.0077, r^{2}=0.9984$, where $Y$ is the ratio of the peak area of the ebeiedinone and the internal standard, and $C$ is the concentration of ebeiedinone in mouse blood. The LLOQ in the mouse blood was $1.0 \mathrm{ng} / \mathrm{mL}$, with a signal-to-noise ratio of 8 . The limit of detection (LOD) was $0.3 \mathrm{ng} / \mathrm{mL}$, with a signal-to-noise ratio of 3 .

As shown in Table 1, the intra-day precision CV was less than $15 \%$, and the inter-day precision $\mathrm{CV}$ was less than $15 \%$. The accuracy ranged from $85.4 \%$ to $114.6 \%$, and the average recovery was higher than $61.3 \%$. The matrix effect was between $87.0 \%$ and $106.5 \%$. These data met the pharmacokinetic study requirements of ebeiedinone.

For the mouse blood at room temperature for $2 \mathrm{~h},-20{ }^{\circ} \mathrm{C}$ for 30 days, and freeze-thaw stability test, the variation of ebeiedinone was within $\pm 12 \%$, and the $\mathrm{CV}$ was less than $11 \%$, indicating that the stability of ebeiedinone was acceptable.

3.3. Pharmacokinetics Study. In this study, the UPLCMS/MS method was used to study the pharmacokinetics of ebeiedinone after intravenous and oral administration. UPLCMS/MS was applied to the quantitative detection of ebeiedinone in mouse blood, which was faster and sensitive than traditional HPLC. It needed only $4 \mathrm{~min}$ to complete the analysis of the plasma sample, saving a lot of time and solvent.

The concentration-time curve of ebeiedinone was shown in Figure 3. The non-compartmental model was fitted to the main pharmacokinetic parameters, as shown in Table 2. As could be seen from Table 2, the absolute bioavailability of the ebeiedinone $(2,4$, and $8 \mathrm{mg} / \mathrm{kg}$ ) was $37.8 \%, 31.3 \%$, and $22.8 \%$, and the average absolute bioavailability was $30.6 \%$. The investigated pharmacokinetics of ebeiedinone could be used to better understand its pharmacology.

\section{Conclusion}

A sensitive, rapid, and selective UPLC-MS/MS method was developed for the determination of ebeiedinone in the mouse blood, with a linear range of $1-2000 \mathrm{ng} / \mathrm{mL}$ and LLOQ of $1.0 \mathrm{ng} / \mathrm{mL}$, and it needed a blood volume of $20 \mu \mathrm{L}$ and only 4 min for one sample run. To the best of our knowledge, the pharmacokinetics of ebeiedinone had not been reported. This method was successfully applied to the pharmacokinetics of ebeiedinone in mice after intravenous $(0.5 \mathrm{mg} / \mathrm{kg})$ and oral $(2,4$ and $8 \mathrm{mg} / \mathrm{kg})$ administration, and the average absolute bioavailability was calculated to be $30.6 \%$.

Acknowledgements. This work was supported by a grant funded by grants from the Zhejiang Basic Public Welfare Research Project (LGF18H270001).

\section{References}

1. Cui, M. C.; Chen, S. J.; Wang, H. H.; Li, Z. H.; Chen, H. J.; Chen, Y; Zhou, H. B.; Li, X.; Chen, J. W. J. Food Drug Anal. 2018, 26, 337-347.

2. Lou, Y.; Cai, H.; Liu, X.; Tu, S.; Pei, K.; Zhao, Y.; Cao, G.; Li, S.; Qin, K.; Cai, B. Pharmacogn. Mag. 2014, 10, S30-S36.

3. Duan, B.; Huang, L.; Chen, S. Phytomedicine 2012, 19, 562-568.

4. Shi, J. Y.; Yuan, X. F.; Lin, H. R.; Yang, Y. Q.; Li, Z. Y. Int. J. Mol. Sci. 2011, 12, 3770-385.

5. Chen, L.; Liu, L.; Zhu, W.; Zhang, H.; Yan, Z.; Liu, H. Pharmazie 2011, 66, 684-689.

6. Yuan, X.; Shi, J.; Yang, Y.; Luan, J.; Gao, J.; Wang, Y. Biol. Trace Elem. Res. 2010, 135, 304-313.

7. Wei, C. B.; Chen, J.; Zhang, Q. Y.; Shi, Y. H.; Lin, L.; Zheng, H. Y.; Adams, M. J.; Chen, J. P. Arch. Virol. 2005, 150, 1271-1280.

8. Cui, M. C.; Zhang, J. Y.; Chen, S. J.; Jiang, H. L.; Zhou, H. B.; Ling, Q. Z. Zhongguo Zhong Yao Za Zhi 2016, 41, 2124-2130.

9. Zhang, Y. N.; Wang, K. C.; Zhang, X. Q.; Cui, Z. W.; Wang, Q. Zhongguo Zhong Yao Za Zhi 2015, 40, 421-423.

10. Yuan, X. F.; Peng, S. M.; Wang, B. L.; Ding, Z. S. Zhongguo Zhong Yao Za Zhi 2014, 39, 4304-4310.

11. Jiang, J. M.; Yu, X. G.; Wang, W. J.; Wang, Z. H.; Shao, J. W.; Wang, Z. A. Zhongguo Zhong Yao Za Zhi 2019, 44, 448-453.

12. Li, S. L.; Chan, S. W.; Li, P.; Lin, G.; Zhou, G. H.; Ren, Y. J.; Chiu, F. C. J. Chromatogr. A 1999, 859, 183-192.

13. Song-Lin, L.; Li, P.; Lin, G.; Chan, S. W.; Ho, Y. P. J. Chromatogr. A 2000, 873, 221-228.

14. Li, T.; Ye, W.; Huang, B.; Lu, X.; Chen, X.; Lin, Y.; Wen, C.; Wang, X. J. Pharm. Biomed. Anal. 2019, 168, 133-137.

15. Li, J.; Jin, Y.; Fu, H.; Huang, Y.; Wang, X.; Zhou, Y. Biomed. Chromatogr. 2019, 33, e4418.

16. Han, A.; Lin, G.; Cai, J.; Wu, Q.; Geng, P.; Ma, J.; Wang, X.; Lin, C. Acta Chromatogr. 2019, 31, 99-104.

17. Chen, M.; Chen, Y.; Wang, X.; Zhou, Y. J. Chromatogr. B: Anal. Technol. Biomed. Life Sci. 2019, 1124, 180-187.

18. Chen, L.; Yang, J.; Chen, D.; Xiong, J.; Wang, X.; Ying, X.; Wei, Y.; Lin, Y.; Zhang, S.; Wu, M. Lat. Am. J. Pharm. 2019, 38, 855-859.

19. (FDA), U.F.a.D.A. ()2018) Guidance for Industry Bioanalytical Method Validation 2018, https://www.fda.gov/downloads/drugs/guidances/ucm070107. Pdf.

20. Shao, L. J.; Jin, Y.; Fu, H. Y.; Ma, J. S.; Wang, X. Q.; Jin, Y. X.; Wen, C. C. J. Anal. Methods Chem. 2018, 2018, 9412708 .

21. Geng, P.; Luo, J.; Weng, Z.; Fan, Z.; Zhang, B.; Ma, J.; Wang, X.; Zhang, M. Biomed. Chromatogr. 2018, 32, e4273.

22. Chen, L. G.; Zhang, B.; Liu, J. L.; Fan, Z. H.; Weng, Z. W.; Geng, P. W.; Wang, X. Q.; Lin, G. Y. BioMed Res. Int. 2018, 2018, 1578643.

23. Ma, J.; Wang, S.; Huang, X.; Geng, P.; Wen, C.; Zhou, Y.; Yu, L.; Wang, X. J. Pharm. Biomed. Anal. 2015, 111, 131-137.

24. Zhang, Q. W.; Wen, C. C.; Xiang, Z.; Ma, J. S.; Wang, X. Q. J. Pharm. Biomed. Anal. 2014, 90, 134-138.

25. Du, J.; Ma, Z.; Zhang, Y.; Wang, T.; Chen, X.; Zhong, D. Bioanalysis 2014, 6, 2343-2356.

26. Liu, J.; Wang, L.; Hu, W.; Chen, X.; Zhong, D. J. Chromatogr. B: Anal. Technol. Biomed. Life Sci. 2014, 971, 35-42.

27. Weng, Q. H.; Weng, T. T.; Lin, Y. J.; Lu, X. J.; Zhong, Z. Q.; Chen, L. G.; Xiong, J. H.; Wang, X. Q. Lat. Am. J. Pharm. 2019, 38, 431-436. 
28. Song, H. C.; Huang, Y. W.; Zhu, D. Q.; Tong, S. H.; Zhang, M. L.; Wang, X. Q.; Bao, X. Curr. Pharm. Anal. 2019, 15, 194-199.

29. Wu, H. Y.; Yan, Q. Z.; Fan, Z. H.; Huang, M. L.; He, J. M.; Ma, J. S.; Wang, X. Q. Biomedical Chromatography 2018, 32, e4255.

30. Wang, H. Y.; Chen, Y. C.; Wan, J. F.; Xu, J. L.; Mo, J. J.; Qian, S. Y.; Zhou, Y. F.; Wang, X. Q.; Huang, G. Lat. Am. J. Pharm. 2018, 37, 17241729.

31. Zhou, Y. F.; Chen, B. B.; Chen, J. Y.; Dong, Y. W.; Wang, S. H.; Wen, C. C.; Wang, X. Q.; Yu, X. M. Acta Chromatogr. 2018, 30, 131-135.

32. Wang, S. H.; Lin, Z. X.; Su, K.; Zhang, J.; Zhang, L. J.; Gao, Z. M.; Wang, Z. Y.; Ma, J. S.; Wang, X. Q. Acta Chromatogr. 2018, 30, 26-30.

33. Zhang, Q.; Wen, C.; Xiang, Z.; Ma, J.; Wang, X. J. Pharm. Biomed. Anal. 2014, 90, 134-8.
34. Li, T.; Ye, W.; Huang, B.; Lu, X.; Chen, X.; Lin, Y.; Wen, C.; Wang, X. J. Pharm. Biomed. Anal. 2019, 168, 133-137.

35. Li, J.; Jin, Y.; Fu, H.; Huang, Y.; Wang, X.; Zhou, Y. Biomed. Chromatogr. 2019, 33, e4418.

36. Ye, W.; Lin, X.; Zhang, Y.; Xu, Y.; Sun, R.; Wen, C.; Wang, X.; Bao, S.; Chen, R. J. Pharm. Biomed. Anal. 2018, 152, 242-247.

37. Geng, P. W.; Zhang, J.; Chen, B. B.; Wang, Q. Q.; Wang, S. H.; Wen, C. C. Acta Chromatogr. 2018, 30, 136-140.

38. Chen, L. G.; You, W. W.; Chen, D. W.; Cai, Y.; Wang, X. Q.; Wen, C. C.; Wu, B. Biomed. Res. Int. 2018, $2018,6562309$.

39. Wang, Y.; Lin, Z. X.; Wang, Q. Q.; Su, K.; Wen, C. C.; Zeng, M.; Wang, X. C. Lat. Am. J. Pharm. 2017, 36, 553-556.

40. Chen, L. G.; Wu, H. Y.; Tu, X. T.; Zhao, Y.; Jiang, Y. Y.; Wen, C. C.; Luo, Y. Acta Chromatogr. 2019, 31, 8-11. 